\title{
Immunotherapy and checkpoint inhibitors for gliomas
}

\author{
Clairice M. Pearce ${ }^{1 \#}$, Matthew R. Chrostek ${ }^{1 \#}$, Emily G. Fellows ${ }^{1}$, Nikolas G. Toman' ${ }^{1}$, Sarah K. Tran'1 Andrew \\ T. Crane ${ }^{1 \# \#, ~ W a l t e r ~ C . ~ L o w ~}{ }^{1,2,3 \# \#}$ \\ 'Department of Neurosurgery, University of Minnesota Medical School, Minneapolis, MN 55455, USA. \\ ${ }^{2}$ Masonic Cancer Center, University of Minnesota Medical School, Minneapolis, MN 55455, USA. \\ ${ }^{3}$ Brain Tumor Program, University of Minnesota Medical School, Minneapolis, MN 55455, USA. \\ \#Authors contributed equally. \\ \#\# Authors contributed equally.
}

Correspondence to: Dr. Walter C. Low, Department of Neurosurgery, University of Minnesota Medical School, 20016 th St SE, Minneapolis, MN 55455, USA. E-mail: lowwalt@umn.edu

How to cite this article: Pearce CM, Chrostek MR, Fellows EG, Toman NG, Tran S, Crane AT, Low WC. Immunotherapy and
checkpoint inhibitors for gliomas. Neuroimmuno/ Neuroinflammation 2018;5:47. http://dx.doi.org/10.20517/2347-8659.2018.46

Received: 2 Aug 2018 First Decision: 23 Aug 2018 Revised: 21 Sep 2018 Accepted: 11 Oct 2018 Published: 15 Nov 2018

Science Editor: Athanassios P. Kyritsis Copy Editor: Cui Yu Production Editor: Zhong-Yu Guo

\begin{abstract}
Glioma treatments are faced with challenges, including the inability to fully eliminate cancer stem cells, the immunosuppressive tumor microenvironment, and the blood brain barrier. Although progress has been made with surgical, radiation, and chemotherapies, prognosis for patients remains poor. Rapidly emerging immunotherapies may be able to address the challenges that conventional techniques cannot. Immunotherapies manipulate the patient's immune system to selectively combat malignancies. Therapies often work to enhance T-cell and natural killer (NK) cell function, which can both eliminate tumor cells and enhance remission. Vaccines encourage in vivo development of anti-tumor T-cells and NK cells, while adoptive transfer techniques focus on engineering immune cells ex vivo before reintroducing them to patients. Vaccine and adoptive transfer therapies have been shown to induce enhanced immune responses in patients but have not always correlated with improved outcomes, likely because of the tumor immunosuppressive microenvironment. Checkpoint inhibitors can impair these tumor immunosuppressive capabilities. Although no one treatment has been able to consistently eliminate gliomas and maintain remission, combinations of vaccines or adoptive transfer techniques in conjunction with immune checkpoint inhibitors offers promise.
\end{abstract}

Keywords: Glioma, immunotherapy, checkpoint inhibitors, vaccines, T-cells, dendritic cells 


\section{INTRODUCTION}

Gliomas arise from different glial cell populations and can manifest as astrocytic tumors (astrocytoma, anaplastic astrocytoma, and glioblastoma), oligodendrogliomas, ependymomas, and mixed gliomas. Glioblastoma multiforme (GBM) is the most malignant, invasive, and common glioma, accounting for over $50 \%$ of all diagnosed brain tumors. A patient with GBM possesses poor prognosis, as typical survival is 14-15 months following diagnosis. Standard treatment includes surgical resection, radiation therapy, and chemotherapy [temozolomide (TMZ)], but these often result in limited success ${ }^{[1]}$. This is partially due to treatment limitations, including infiltration of GBM cells to surrounding brain tissue, intratumoral heterogeneity, and therapy passage across the blood brain barrier $(\mathrm{BBB})^{[2]}$.

The central nervous system (CNS) has long been considered an immune-privileged site, evidenced by the presence of the $\mathrm{BBB}$, lack of lymphatic vessels, and absence of major histocompatibility complex (MHC) - positive antigen presenting cells (APCs) ${ }^{[3]}$. However, recent work suggests that the CNS has a closer relationship with the peripheral immune system. Soluble antigens of the cerebrospinal fluid drain into the cervical lymph nodes, providing $\mathrm{T}$ cells activation before transport to the site of inflammation ${ }^{[4]}$. Leukocytes are known to gain partial access to the CNS through the choroid plexus, across the superficial leptomeningeal vessels, and into the perivascular space ${ }^{[5,6]}$. Brain tumor progression further compromises the integrity of the $\mathrm{BBB}$, allowing these $\mathrm{T}$ cells access to the brain ${ }^{[7]}$. Given that immune cells can permeate the $\mathrm{BBB}$ while maintaining cancer cell-specific targeting, immunotherapies have begun to establish their promise in GBM treatment.

In this review, we will examine recent advances made in immunotherapies for GBM, focusing on harnessing apoptotic functions in natural killer (NK) cells, blocking checkpoint inhibitors to unmask malignancies, and inducing systemic response by vaccine administration to target tumors. We will also highlight clinical trials using these immunotherapies. Finally, we will address therapy challenges and discuss the need for further refinement in applications specific to brain tumors.

\section{T-CELLS}

The ratio of $\mathrm{CD}_{4}^{+}$and $\mathrm{CD}^{+}$T-cells is a prognostic marker in many malignancies and has been found to inversely correlate with progression-free survival and overall survival (OS) in $\mathrm{GBM}^{[8]}$, demonstrating an avenue for immunotherapy intervention.

T-cells maturing in the thymus may develop into $\mathrm{CD} 4^{+}$or $\mathrm{CD} 8^{+} \mathrm{T}$-cells, also known as helper T-cells or cytotoxic T-cells, respectively. They are activated upon APC interaction. APCs recognize pathogenassociated molecular patterns (PAMPs) via pattern recognition receptors, such as toll-like receptors. Once PAMPs are recognized before or during endocytosis, antigens, usually peptides, are loaded onto MHC-I or MHC-II proteins. Antigens that are loaded onto MHC-II proteins activate $\mathrm{CD} 4{ }^{+} \mathrm{T}$-cells, which further activate $\mathrm{CD} 8^{+} \mathrm{T}$-cell responses. This contrasts with antigens that are loaded onto MHC-I proteins, which activate only $\mathrm{CD}^{+}{ }^{\mathrm{T}}$-cells ${ }^{[9]}$.

Induction of helper T-cell differentiation from $\mathrm{CD} 4{ }^{+} \mathrm{T}$-cells is orchestrated by cytokine stimulation ${ }^{[10]}$. Helper T-cells promote anti-tumor response by secreting pro-inflammatory cytokines interferon (IFN)- $\gamma$ and tumor necrosis factor (TNF). These cytokines then activate death receptors on the tumor cell surface, consequently triggering dendritic cell (DC) cytotoxic functions. It is these functions that eradicate tumor cells. T regulatory cells (Tregs) often modulate the immune response through the secretion of anti-inflammatory cytokines tumor growth factor- $\beta$ and interleukin (IL)-10. While Treg cytokine secretion is aimed to prevent a dramatic immune response, Tregs may inadvertently contribute to tumor development by suppressing proinflammatory anti-tumor responses ${ }^{[11]}$. 
$\mathrm{CD}^{+}$and $\mathrm{CD}^{+}$T-cells can further differentiate into effector or memory T-cells, which are essential in delivering a robust secondary immune response after re-exposure to antigen ${ }^{[10]}$. $\mathrm{CD}^{+}{ }^{+}$effector T-cells attack tumor cells by releasing perforin and granzyme cytotoxic molecules and producing pro-inflammatory cytokines TNF and IFN- $\gamma$. During antigen clearance, most $\mathrm{CD}^{+}{ }^{+}$effector T-cells undergo apoptosis, with a small margin surviving. When high levels of antigens persist in an environment, these remaining $\mathrm{CD}^{+}$ T-cells progress into a state of T-cell exhaustion. This situation is commonly seen in cancers with solid tumors like GBM. In the T-cell exhaustive state, inhibitory receptors are overexpressed, cytokine signaling pathways are dysregulated, and altered metabolic fitness occurs ${ }^{[12]}$, leading to altered T-cell functioning and unrestrained tumor growth. Novel strategies and new approaches have been developed in attempts to circumvent these hurdles to immunotherapy for gliomas.

\section{ADOPTIVE T-CELL TRANSFER}

Adoptive T-cell transfer (ACT) involves the collection and ex vivo expansion of autologous anti-tumor T lymphocytes. These cells are then reinfused into the patient, delivering a potent and focused response. This approach provides the immune system and tumor microenvironment with an already abundant, activated T-cell population that can proliferate in vivo to maintain antitumor functions. ACT therapy can provide benefits to immunocompromised patients as it eliminates the need for self-induced antigen presentation. This feature, along with the ability for T-cells to bypass the BBB, suggests that ACT may be particularly effective in brain tumor treatment ${ }^{[13]}$.

There are several avenues to the ACT approach, but the furthest advanced is the chimeric antigen receptor T-cell (CAR T) therapy. After isolating T-cells from the patient, these cells are genetically engineered to express receptors that mediate tumor cell destruction after reinfusion to patients. CAR T targeting of B cell marker CD19 has shown great efficacy in lymphoblastic leukemia and B cell lymphomas, but applications in the treatment of solid tumors have only begun to be explored ${ }^{[1,15]}$. Progress has been made in CAR T treatments for brain tumor targeting, particularly utilizing epidermal growth factor receptor (EGFR)vIII [Table 1]. Given that EGFRvIII is known to be prevalent in gliomas, CAR was directed against EGFRvIII and used in a phase I clinical trial for recurrent $\mathrm{GBM}^{[16]}$. All patients given CAR T EGFRvIII intravenous infusions exhibited decreased expression of EGFRvIII in tumors, indicative of CAR on-target effects. Flow cytometric analysis of $\mathrm{CD}^{+}{ }^{+}$T-cells detected engraftment of CAR T-EGFRvIII cells in the peripheral blood. These findings demonstrated CAR T transient growth advantage as compared to endogenous lymphocytes, and that rescue of normal T-cell activity can be achieved. This is especially applicable to immunocompromised patients previously administered doses of TMZ and radiation. None of the infused subjects presented symptoms of tumor toxicity nor cytokine release syndrome, and there was no crossreactivity of wild type $\mathrm{EGFR}^{[17]}$.

Other clinical trials have shown that through administration of glioma associated antigen IL13R $\alpha 2$ in CAR T-cells, patients with recurrent GBM showed transient, anti-tumor responses. In metastatic GBM, significant tumor regression could be observed after 4-1BB co-stimulation and a mutated IgG4-Fc linker was incorporated into administered CAR T-cells which enhance antitumor potency and reduced off target interactions. While both intracavitary and intraventricular administration of CAR T populations was performed, intraventricular administration was found to achieve regression of all CNS tumors ${ }^{[18]}$. These preliminary findings illustrate the potential for CAR T mass manufacture, designed to address function and toxicity deficiencies.

Challenges in transitioning ACT to the clinic include the risk of inducing graft $v s$. host disease, which may arise through allogeneic T-cell transfusion. Identification of toxicity prior to human administration is another challenge, largely due to the lack of representative immune systems in pre-clinical models. Introduction of a robust T-cell population carries its drawbacks. Off-targeting can present as cross-reactivity of the T-cell receptor with an antigen that possesses similar structure to the target antigen. This can result in 
Table 1. Clinical trials using adoptive T-cell transfers to treat gliomas

\begin{tabular}{|c|c|c|c|c|}
\hline Identifier & Trial name & Treatment & Phase & $\begin{array}{l}\text { Diagnosis (newly } \\
\text { diagnosed or } \\
\text { reoccur ring) }\end{array}$ \\
\hline NCT02844062 & $\begin{array}{l}\text { Pilot study of autologous anti-EGFRvIII CAR T-cells in } \\
\text { recurrent GBM }\end{array}$ & Autologous anti-EGFRvIII CAR T & 1 & Reoccurring \\
\hline NCT03283631 & $\begin{array}{l}\text { Intracerebral EGFRvIII CAR-T-cells for recurrent GBM } \\
\text { (intercept) }\end{array}$ & Autologous anti-EGFRvIII CAR T & 1 & Reoccurring \\
\hline NCT03389230 & $\begin{array}{l}\text { Memory-enriched T-cells in treating patients with } \\
\text { recurrent or refractory grade III-IV glioma }\end{array}$ & $\begin{array}{l}\text { Leukapheresis, autologous } \\
\text { HER2(EQ)BBC/CD19t+ }\end{array}$ & 1 & Reoccurring \\
\hline NCT03423992 & $\begin{array}{l}\text { Personalized CAR T immunotherapy for patients with } \\
\text { recurrent malignant gliomas }\end{array}$ & $\begin{array}{l}\text { Autologous anti-EGFRvIII, IL13R } \alpha 2, \\
\text { HER2, CD133, EphA2, GD2 CAR T }\end{array}$ & I & Reoccurring \\
\hline NCT02208362 & $\begin{array}{l}\text { Genetically modified T-cells in treating patients with } \\
\text { recurrent or refractory malignant glioma }\end{array}$ & $\begin{array}{l}\text { IL13R } \alpha 2 \text {-specific, hinge-optimized, } \\
\text { 41BB-costimulatory } \\
\text { CAR/truncated CD19-expressing } \\
\text { autologous T lymphocytes }\end{array}$ & 1 & Reoccurring \\
\hline NCT02209376 & $\begin{array}{l}\text { Autologous T-cells redirected to EGFRVIII - with a chimeric } \\
\text { antigen receptor in patients with EGFRVIII + GBM }\end{array}$ & CAR T-EGFRvIII T-cells & I & Patients with residual \\
\hline
\end{tabular}

EGFR: epidermal growth factor receptor; CAR T: chimeric antigen receptor T-cell; GBM: glioblastoma multiforme; HER2: human epidermal growth factor receptor 2

cytotoxic effects to otherwise healthy tissue ${ }^{[19]}$. Conversely, toxicities can also arise through on-target effects. This generally manifests as successful binding to the antigen expressed in environments not specific to the tumor $^{[20]}$. Cytokine release syndrome is another condition that results from the release of mass quantities of cytokines, an indirect result of the release of mass quantities of T-cells ${ }^{[21]}$. However, downregulation in the prevalence of these cytokines can be achieved by receptor blockage. Specifically, in treatment focused on acute lymphoblastic leukemia, a patient administered tocilizumab (an IL-6 receptor inhibitor) was able to reverse cytokine storm syndrome symptoms yet still maintained the T-cell population and continued to derive benefits from ACT therapy ${ }^{[22]}$. Thus, while these side effects are serious, continued refinement protocols can be made so symptoms are less severe and more manageable.

Current efforts in ACT aim to target solid tumors and optimize gene transfer. Methods of achieving gene transduction to $\mathrm{T}$ lymphocytes include retroviral and lentiviral gene delivery. Positive efficacy in gene transduction may be observed, but integration of genes may prefer certain areas of the genome over others. Poor integration of genes could result in mutagenesis and overexpression or disruption of nearby genes in $\mathrm{T}$-cells ${ }^{[23,24]}$. Additionally, patients' immune systems may react to the vectors themselves, and these genotoxic events may interfere with T-cell delivery. To circumvent these issue, engineering of CAR T-cells by piggyBac and Sleeping Beauty transposons has gained momentum ${ }^{[25,26]}$. These methods offer reduced manufacture cost, increased simplicity, and less good manufacturing practice requirements. Gene expression remains unperturbed and foreign proteins that could result in adverse effects are absent. Treatments utilizing Sleeping Beauty have just reached phase I clinical trials ${ }^{[27]}$. Optimization and precision of these transposon systems may prove crucial to improved ACT safety.

\section{NK CELLS}

NK cells demonstrate potent anti-tumor immunity. Unlike T-cells, transfusions of NK cells are not complicated by graft-host-disease. NK cells detect and eliminate cell abnormalities and are found in lymphoid and non-lymphoid organs ${ }^{[28]}$. Activated NK cells secrete perforin and granzymes to induce apoptosis in target cells. Ligands like killer immunoglobulin-like receptors are expressed on healthy cells and can inhibit the destructive activity of NK cells. Antibodies, cytokines, natural cytotoxicity receptors and transmembrane protein $\mathrm{NK} 2 \mathrm{GD}$ on infected or transformed cells provide activating signals to NK cells ${ }^{[29]}$. Conversely, downregulation of MHC-I in tumor cells depletes inhibitory signals to NK cells. It is these shifts between activating and inhibitory signals that allow NK cells to selectively target abnormal cells. This is the premise of anti-tumor NK cell immunotherapies ${ }^{[30]}$. 
Studies aimed at heightening NK cell activity for immunotherapies have done so through genetic engineering or by stimulation of NK cells directly in vivo or ex vivo [Table 2]. The tumor microenvironment is known to be immunosuppressive which correlates with reduced NK cell activity ${ }^{[31]}$. Because of this, few NK cells achieve activation to carry out NK cell-mediated lysis. By stimulating NK cells, however, the immunosuppressive tumor microenvironment may be overcome. Efforts to stimulate NK cell proliferation and activity have focused on exposure of NK cells to cytokines including IL-2, 12, 15, 18 and 21. Once stimulated, NK cells become lymphokine-activated killer cells. These cells have demonstrated increased levels of cytotoxicity towards malignant tumors and proliferate at a greater rate ${ }^{[29]}$.

Clinically, NK cell stimulation with IL-2 was approved for treatment of metastatic renal cancer by the FDA in 1992. High-doses of IL-2 has demonstrated efficacy in treating various cancers, but increasing doses also increases the risk of severe adverse effects. A phase III trial comparing IL-2 doses for liver and bone metastases and primary tumors showed that the response rate for high-dose IL-2 was significantly higher than all other groups. It was concluded high-dose IL-2 were necessary for significant clinical benefits, despite the possible negative effects ${ }^{[32]}$.

IL-21 stimulates NK cells and $\mathrm{CD} 8^{+}$T-cells while also increasing the production of IFN- $\gamma$. Together with IL-2 and IL-15, IL-21 enhances cytotoxic effects of NK and $\mathrm{CD}^{+} \mathrm{T}_{-}-\mathrm{cells}^{[33]}$. A phase II clinical study treating melanoma patients with IL-21 found that antitumor efficacy of IL-21 is comparable to that of high-dose IL-2. The treatments were well tolerated among patients and resulted in few adverse actions ${ }^{[34]}$.

IL-15 has been tested in phase I trials to monitor the reactions among patients after administration. The cytokine was given as bolus intravenous infusions to patients with metastatic malignant melanoma and renal cell cancer. The treatments caused a large swing in the distribution of lymphocytes within the blood, suggesting its importance to the activation of NK cells and their cytotoxicity. Many adverse reactions were recorded, however, which is thought to be the result of the method of administration ${ }^{[35]}$.

IL-12 is another cytokine under investigation for use in immunotherapy. Studies in preclinical models using IL-12 have shown strong antitumor effects ${ }^{[36]}$. In one such study, the rejection of gliomas in mice was found to be significantly enhanced in those expressing IL-12 in the CNS, as compared to those without ${ }^{[37]}$. This gives evidence that the expression of IL-12 cytokine can be a major factor in anti-tumor response through stimulation of the immune system.

NK cell function is heavily dependent on cytokine support. But, even with administration of additional cytokines, the tumor microenvironment may limit NK cell activation. To overcome dependence on exogenous cytokines, genetically engineered NK cells have been explored for their ability to surpass the tumor microenvironment. One study examined whether transduced expression of a nonsecretory, membrane-bound form IL-15 (mbIL15) could sustain NK cells. The mbIL15 NK cells had enhanced survival and viability compared to mock-transduced NK cells and NK cells that expressed non-membrane bound IL-15. Because mbIL15 NK cells are less dependent on endogenous signaling molecules, their activity and cytotoxicity against solid tumors is resilient to immunosuppressant effects of the tumors ${ }^{[38]}$. Genetic engineering of NK cells to self-activate may prove more effective than stimulation from endogenous cytokines. Engineered NK cells avoid off targeting effects of cytokine administration to patients and may allow for NK cell antitumor functions to be enhanced. Patients with esophageal squamous cell carcinoma, squamous cell lung cancer, and gastric carcinoma have shown positive responses to NK treatments. Higher survival rates were correlated to CD57 positive cells at the site of the tumor. CD57 expression is associated with NK cells, as well as T-cells, and may serve as an additional target for enhancing NK cell effectiveness. Clinical trials to assess the efficacy of NK therapy for gliomas have now been initiated [Table 2] with peerreviewed reports yet to be released. 
Table 2. Progress using natural killer cells against cancer clinical trials

\begin{tabular}{|c|c|c|c|c|}
\hline Identifier & Trial name & Treatment & Phase & Diagnosis \\
\hline NCT03383978 & $\begin{array}{l}\text { Intracranial injection of NK- 92/5.28.z (HER2. } \\
\text { taNK) cells in patients with recurrent HER2- } \\
\text { positive GBM (Quilt 3.C001) (CAR2BRAIN) }\end{array}$ & $\begin{array}{l}\text { NK-92/5.28.z (HER2. } \\
\text { taNK) injection }\end{array}$ & I & GBM \\
\hline NCT00909558 & $\begin{array}{l}\text { Safety and effectiveness study of autologous NK } \\
\text { and NK T-cells on cancer }\end{array}$ & $\begin{array}{l}\text { Autologous NK/NK } \\
\text { T-cell immunotherapy }\end{array}$ & I & $\begin{array}{l}\text { Glioma, squamous cell lung cancer, } \\
\text { pancreatic cancer, colon cancer }\end{array}$ \\
\hline NCT00823524 & $\begin{array}{l}\text { Donor NK cells after donor stem cell transplant } \\
\text { in treating patients with advanced cancer }\end{array}$ & Donor NK cell infusion & I/II & $\begin{array}{l}\text { Brain and central nervous system } \\
\text { tumors }\end{array}$ \\
\hline NCT03081780 & $\begin{array}{l}\text { Open label NK cell infusion (FATE-NK100) with } \\
\text { Subq IL-2 in adults with AML }\end{array}$ & FATE-NK100 & I & $\begin{array}{l}\text { Refractory acute myelogenous } \\
\text { leukemia, relapsed AML }\end{array}$ \\
\hline
\end{tabular}

NK: natural killer; GBM: glioblastoma multiforme; HER2: human epidermal growth factor receptor 2; AML: acute myelogenous leukemia

\section{CHECKPOINT INHIBITORS}

Checkpoint inhibitors are a rapidly advancing field and involve the exploitation of tumor checkpoint regulators. Immune checkpoints regulate the life cycle of the cellular immune response by either activation of signals or by inhibition of activating processes. Tumor checkpoint regulators are mechanisms by which tumors evade immune system recognition through expression of neoantigens. These antigens emulate those of healthy tissue ${ }^{[30]}$. Checkpoint inhibition blocks tumor cell evasion and allows for T-cells to overcome the immunosuppressive tumor microenvironment. However, clinical trial outcomes and patient responses differ between cancer types. Thus, investigation of external influences on checkpoint mechanisms ought to be further explored.

Inhibitors generated for therapeutic use are found as chemically synthesized monoclonal antibodies or recombinant forms of ligands or receptors. Such checkpoint targets include the programmed death receptor 1 (PD-1) and its ligand (PD-L1) or cytotoxic T-lymphocyte associated protein 4 (CTLA-4) receptor and its ligands CD80 and CD86. These pathways are responsible for restriction of T-cells in peripheral tissues during inflammatory response or for down-regulation of co-stimulatory T-cells, respectively ${ }^{[40-42]}$. Although the PD-1 and CTLA-4 pathways are not the only mechanisms which provide cancer cells protection from T-cell surveillance, PD-1 and CTLA-4 have exhibited profound outcomes in regard to tumor regression, appear to possess an immunodominant role as compared to other immune checkpoints, and their mechanisms are the most understood. It has been shown that PD-L1 is highly expressed on tumor cells and that coordination between PD-1/PD-L1 can inhibit $\mathrm{CD}^{+}{ }^{\mathrm{T}}$-cell function ${ }^{[43]}$. Administration of PD-L1 inhibitors results in regression of a number of tumor types ${ }^{[44-49]}$. CTLA-4 blockade has shown efficacy in murine melanoma, prostate cancer, and pancreatic carcinoma studies ${ }^{[0,51]}$. The latter demonstrated particular success when combined with PD-1 inhibition, as survival was prolonged even after tumor rechalleng ${ }^{[52]}$. This finding is applicable to cancer cells that remain concealed within the body following tumor resection.

Despite checkpoint inhibitor success in various cancer types, use of this therapy against brain tumors has yet to be extensively pursued. Preclinical assessments in orthotopic, immunocompetent murine models have identified the most effective checkpoint pathway against GBM. When administered alone, PD-1 inhibition has a 50\% long term survival rate in mice. Combined treatment with PD-1 and CTLA-4 inhibition was found to achieve $75 \%$ long term survival ${ }^{[53]}$. These results paralleled those found in a melanoma clinical trial that utilized the same combination of inhibitors, indicating improved effectiveness ${ }^{[54]}$. Furthermore, checkpoint inhibitor OX-2 glycoprotein (CD200) has been found to be highly expressed in a number of human brain tissue samples, including astrocytomas, meningiomas, and GBM tumors ${ }^{[55]}$. This pathway has been investigated in canine models with high-grade gliomas. Although CD200 canine clinical trials are still ongoing, regression of tumors and absence of inhibitor toxicity has indicated therapeutic promise, and treated groups have already demonstrated an increase of 615 days of survival as compared to control subjects $^{[56]}$. Another pursuit made to target meningioma and other rare CNS tumors is an ongoing, Phase II 
Table 3. Clinical trials using checkpoint inhibitors to treat central nervous system tumors

\begin{tabular}{|c|c|c|c|c|}
\hline Identifier & Trial name & Treatment & Phase & $\begin{array}{c}\text { Diagnosis (newly } \\
\text { diagnosed or reoccurring) }\end{array}$ \\
\hline NCT02866747 & $\begin{array}{l}\text { A study evaluating the association of hypofractionated } \\
\text { stereotactic radiation therapy and durvalumab for patients } \\
\text { with recurrent GBM (STERIMGLI) }\end{array}$ & $\begin{array}{l}\text { Durvalumab (PD-L1), } \\
\text { radiotherapy }\end{array}$ & I/II & Reoccurring \\
\hline NCT02311920 & Immune-related DLTs & $\begin{array}{l}\text { Pilimumab (CTLA-4), } \\
\text { nivolumab (PD-1), TMZ }\end{array}$ & I & Both \\
\hline NCT03173950 & $\begin{array}{l}\text { Immune checkpoint inhibitor nivolumab in people with select } \\
\text { rare CNS cancers }\end{array}$ & Nivolumab (PD-1) & ॥ & Newly diagnosed \\
\hline NCT02617589 & $\begin{array}{l}\text { An investigational immuno-therapy study of nivolumab } \\
\text { compared to TMZ, each given with radiation therapy, for } \\
\text { newly-diagnosed patients with GBM (CheckMate 498) }\end{array}$ & $\begin{array}{l}\text { Nivolumab (PD-1), } \\
\text { radiotherapy, TMZ }\end{array}$ & III & Newly diagnosed \\
\hline NCT02320058 & $\begin{array}{l}\text { An investigational immuno- therapy study to evaluate safety } \\
\text { and effectiveness in patients with melanoma that has spread } \\
\text { to the brain, treated with nivolumab in combination with } \\
\text { ipilimumab, followed by nivolumab by itself (CheckMate 204) }\end{array}$ & $\begin{array}{l}\text { Ipilimumab (CTLA-4), } \\
\text { nivolumab (PD-1) }\end{array}$ & II & Both \\
\hline
\end{tabular}

GBM: glioblastoma multiforme; PD-1: programmed death receptor 1; PD-L1: programmed death receptor ligand 1; DLTs: dose limiting toxicities; CTLA-4: cytotoxic T-lymphocyte associated protein 4; TMZ: temozolomide; CNS: central nervous system

clinical trial utilizing PD-1 inhibitor nivolumab (NCT03173950). This progress emphasizes the importance of continued clinical efforts with checkpoint inhibitors.

Combinatorial methods using checkpoint inhibitors have also been under investigation [Table 3]. Mice implanted with GL261 gliomas treated with both stereotactic radiotherapy and PD-1 inhibitors have shown improved median survival compared to untreated mice. This is thought to be due to increased MHC-I expression and inhibited PD-1 expression, ultimately provoking an increased $\mathrm{CD} 8^{+}$effector $\mathrm{T}$ and decreased Treg population. 15\%-40\% of mice became long-term survivors, and mice rechallenged with GL261 demonstrated systemic immunity ${ }^{[57]}$. Nivolumab coupled with radiotherapy presents a similar treatment combination, and the therapy is currently being explored in one of the first phase III clinical trials for GBM. The results have not yet been published (NCT02617589). Investigation of anti-PDL1 durvalumab combined with hypofractionated stereotactic radiotherapy to target recurrent GBM has paved the way for a phase II clinical trial, with an absence of serious adverse events and dose-related toxicity related to treatment in patients (NCT02866747). Combined administration of nivolumab and ipilimumab to patients with untreated melanoma metastatic to the brain demonstrated success in a phase II clinical study, with OS rates reaching $92.3 \%$ and $82.8 \%$ at 6 and 9 months respectively (NCT02320058). Four-1BB is another antibody that prompts $\mathrm{CD}^{+}$and memory $\mathrm{T}$ cell proliferation upon activation. A study in mice combining radiation, CTLA-4 blockade, and 4-1BB activation achieved a minimum of 50\% long-term tumor free survival, and the treatment increased populations of $\mathrm{CD}^{+}$and $\mathrm{CD}^{+}$tumor infiltrating lymphocytes. Tumor cells were also rejected after re-challenge ${ }^{[58]}$. Finally, a study utilized the catabolic tryptophan enzyme indoleamine 2,3 dioxygenase 1 (IDO), because it is upregulated in $90 \%$ of GBM cases, absent in healthy tissue and is also known to play a significant immunosuppressive role in the tumor microenvironment. Combined inhibitors for CTLA-4, PD-L1, and IDO (1-methyl-tryptophan) were administered to mice and resulted in 100\% survival ${ }^{[59]}$. Because unperturbed CTLA-4, PD-L1, and IDO pathways greatly augment immunosuppression, it is thought that pathway inhibition should reduce Tregs and result in positive survival outcomes.

One challenge in checkpoint inhibition therapy is identifying which patients might derive the greatest benefit. Prognostic biomarkers must still be defined. The current means of predicting treatment outcome for the PD-1/PD-L1 pathway is by immunohistochemistry of cytologic tumor samples. This method is not completely reliable, as samples are susceptible to contamination and the interpretation of ambiguous finding ${ }^{[60,6]}$. CTLA-4 does not have clinically relevant biomarkers.

Further confounding the process, it is possible that the expression of checkpoint ligands or receptors on tumors may not always be reliable in determining treatment outcomes. In melanoma, for instance, PD-L1 
presence on tumors is indicative of survival outcomes, because ligand expression is dependent on $\mathrm{CD} 8^{+}$ T-cells and IFN- $\gamma$ secretion. However, $\mathrm{CD}^{+}{ }^{+}$dependence may be specific to melanoma patients, as PD-L1 checkpoint inhibition therapy has demonstrated improved survival with non-small cell lung cancer even if classified as PD-L1 negative ${ }^{[62]}$. Similarly, expression of PD-L1 has not been definitively correlated with prognosis in GBM, suggesting the ligand is not a reliable biomarker ${ }^{[63]}$. Recent work has aimed to explain the immune-resistance of some tumors. Genes in $\beta$-catenin, peroxisome proliferator-activated receptor- $\gamma$, and fibroblast growth factor receptor 3 pathways were found to be responsible for failed $\mathrm{T}$ cell priming and recruitment in the urothelial bladder tumor microenvironment in mice. This ultimately led to poor results in checkpoint inhibitor treatment ${ }^{[64]}$. Similar results were found in another study. $\beta$-catenin presence in murine BP-SIY tumors is responsible for preventing migration of effector $\mathrm{T}$ cells and a robust immune response succeeding $\mathrm{ACT}^{[65]}$. In application to transcriptome signatures, these data may allow for more reliable tumorspecific biomarkers options and could improve effectiveness in the total patient population. Because higher mutational load of the tumor has been associated with more effective immunotherapeutic outcomes using checkpoint inhibitors, assays exploring tumor mutational burden are also currently being pursued ${ }^{[66]}$.

These preclinical studies suggest that the mechanism of checkpoint inhibitors is more complex than once thought. Until recently, our gaps in understanding the mechanisms regarding checkpoint inhibition were mostly due to the absence of in vivo models representative of the human immune system. However, headway has been made in the development of new models. For instance, we know an exhausted $\mathrm{CD}^{+}$ T-cell population surrounds GBM tumors in humans and that this state is achieved through prolonged exposure to the tumor antigen ${ }^{[67]}$. To emulate these conditions in the laboratory, a murine model was generated by infection with chronic lymphocytic choriomeningitis virus followed by induction of murine glioma. This tumor positively responded to anti PD-1 treatment ${ }^{[68]}$. A model for human hematopoietic and immune systems was generated in nonobese diabetic Cg-PrkdcscidIL2rgtmiWjl/Sz mice by transplantation of human $\mathrm{CD}_{34}{ }^{+}$hematopoietic progenitor and stem cells. Patient-derived tumor xenografts in this model responded positively to PD-1 checkpoint inhibitor pembrolizumab ${ }^{[69]}$. Studies utilizing these models should provide a more clear representation of the mechanisms and effects of checkpoint inhibition on human tumors. Through continued efforts, distinct biomarkers can be established for these therapies, and a push for additional clinical trials pursued.

\section{VACCINE THERAPIES}

\section{Peptide Vaccines}

Peptide vaccines have been widely studied for immunotherapy due to their cost-effectiveness, reproducibility, specificity, and low risk of generating an autoimmune response. Peptide vaccines stimulate the immune system by activating $\mathrm{CD}^{+}$and $\mathrm{CD} 4^{+}$T-cells via APCs. By developing peptides specific to tumors, peptide vaccines can be used to induce an anti-tumor immune response to combat GBM. A limitation of this therapy, however, is the capability of GBM cells to down-regulate MHC-I expression and increase prostaglandin E2 production, which in turn downregulates MHC-II expression on APCs. Furthermore, patient MHC heterogeneity and changes in MHC expression restrict the use of peptide vaccines. To overcome MHC-dependence, long synthetic peptides encoding multiple MHC class I and II epitopes have been developed which are more efficiently processed by DCs and associated with increased $\mathrm{CD} 4^{+}$and $\mathrm{CD} 8^{+}$ T lymphocyte activation ${ }^{[70,71]}$.

Antigens used in peptide vaccines can be tumor-specific antigens which are often the products of mutations or splice variants, or tumor-associated antigens which are overexpressed gene products that can be expressed in tumor cells. While tumor-specific antigens result in precise targeting of the tumor, they are not expressed by a majority of the patient population. Conversely, tumor-associated antigens are shared by a larger patient population and have been more preferentially used in vaccines as immunotherapies ${ }^{[72]}$. Adjuvants often supplement antigens to improve immunogenicity. Common adjuvants include PAMPs, damage-associated molecular patterns, or cytokines that can activate APCs and lymphocytes. 
Table 4. Clinical trials using peptide vaccines to treat glioblastoma multiforme

\begin{tabular}{|c|c|c|c|c|}
\hline Identifier & Trial name & Treatment & Status & $\begin{array}{l}\text { Diagnosis (newly } \\
\text { diagnosed or } \\
\text { reoccurring) }\end{array}$ \\
\hline NCT02149225 & GAPVAC Phase I trial in newly diagnosed GBM patients & $\begin{array}{l}\text { Patient-tailored APVAC vaccine } \\
\text { plus poly-ICLC and GM-CSF }\end{array}$ & I & Newly diagnosed \\
\hline NCT01250470 & $\begin{array}{l}\text { Phase I study of safety, tolerability and immunological effects } \\
\text { of SVN53-67/M57-KOH in patients with survivin-positive } \\
\text { malignant gliomas }\end{array}$ & $\begin{array}{l}\text { Montanide ISA-51/survivin } \\
\text { peptide vaccine with GM-CSF }\end{array}$ & I & Both \\
\hline NCT01222221 & $\begin{array}{l}\text { A cancer research UK Phase I trial of IMA950 (a novel } \\
\text { multi-peptide vaccine) plus GM-CSF in patients with newly } \\
\text { diagnosed GBM }\end{array}$ & IMA-950 vaccine with GM-CSF & I & Newly diagnosed \\
\hline NCT00626015 & Zenapax ${ }^{\circledR}$-activated peptide immunotherapy & $\begin{array}{l}\text { PEP-3 KLH conjugate vaccine } \\
\text { with daclizumab }\end{array}$ & I & Newly diagnosed \\
\hline NCT00069940 & $\begin{array}{l}\text { A Phase I study of vaccination with telomerase peptide plus } \\
\text { GM-CSF }\end{array}$ & $\begin{array}{l}\text { 540-548 telomerase peptide } \\
\text { vaccine with GM-CSF }\end{array}$ & । & Both \\
\hline NCT00643097 & $\begin{array}{l}\text { A complementary trial of an immunotherapy vaccine against } \\
\text { tumor-specific EGFRvllI }\end{array}$ & $\begin{array}{l}\text { PEP-3 KLH conjugate vaccine } \\
\text { with GM-CSF }\end{array}$ & II & Newly diagnosed \\
\hline NCT01498328 & $\begin{array}{l}\text { A Phase II study of rindopepimut/GM-CSF in patients with } \\
\text { relapsed EGFRvIII-positive GBM }\end{array}$ & $\begin{array}{l}\text { PEP-3 KLH conjugate vaccine } \\
\text { with GM-CSF and bevacizumab }\end{array}$ & $\|$ & Reoccurring \\
\hline NCT00458601 & $\begin{array}{l}\text { A Phase II study of CDX-110 with radiation and temozolomide } \\
\text { in patients with newly diagnosed GBM }\end{array}$ & $\begin{array}{l}\text { PEP-3 KLH conjugate vaccine } \\
\text { with GM-CSF }\end{array}$ & II & Newly diagnosed \\
\hline NCT01920191 & $\begin{array}{l}\text { Phase I/II study of intradermal IMA- } 950 \text { peptide-based } \\
\text { vaccine adjuvanted with intra muscular poly-ICLC in } \\
\text { combination with temozolomide in newly diagnosed HLA-A2 } \\
\text { GBM patients }\end{array}$ & $\begin{array}{l}\text { IMA-950 vaccine with poly- } \\
\text { ICLC }\end{array}$ & II & Newly diagnosed \\
\hline NCT01480479 & $\begin{array}{l}\text { An international, randomized, double- blind, controlled study } \\
\text { of rindopepimut/GM-CSF with adjuvant temozolomide in } \\
\text { patients with newly diagnosed, surgically resected, EGFRvIll- } \\
\text { positive GBM }\end{array}$ & $\begin{array}{l}\text { PEP-3 KLH conjugated vaccine } \\
\text { with GM-CSF }\end{array}$ & III & Newly diagnosed \\
\hline NCT03422094 & $\begin{array}{l}\text { A pilot study to assess the safety, feasibility, and } \\
\text { immunogenicity of a neoantigen-based personalized vaccine } \\
\text { combined with immune checkpoint blockade therapy in } \\
\text { patients with newly diagnosed, unmethylated GBM }\end{array}$ & $\begin{array}{l}\text { Neovax with poly-ICLC, } \\
\text { nivolumab, and ipilimumab }\end{array}$ & $\begin{array}{l}\text { Active, } \\
\text { recruiting }\end{array}$ & Newly diagnosed \\
\hline NCT03223103 & $\begin{array}{l}\text { Phase I study of tumor treatment fields and a personalized } \\
\text { mutation-derived tumor vaccine in patients with newly } \\
\text { diagnosed GBM }\end{array}$ & $\begin{array}{l}\text { MTA-based vaccine with poly- } \\
\text { ICLC and TTF }\end{array}$ & $\begin{array}{l}\text { Active, not } \\
\text { recruiting }\end{array}$ & Newly diagnosed \\
\hline NCT02455557 & $\begin{array}{l}\text { A Phase II study of the safety and efficacy of SVN53-67/M57- } \\
\text { KLH (SurVaxM) in survivin-positive newly diagnosed GBM }\end{array}$ & $\begin{array}{l}\text { SVN53-67-KLH peptide vaccine } \\
\text { with GM-CSF }\end{array}$ & $\begin{array}{l}\text { Active, not } \\
\text { recruiting }\end{array}$ & Newly diagnosed \\
\hline
\end{tabular}

GBM: glioblastoma multiforme; GM-CSF: granulocyte-macrophage colony-stimulating factor; KLH: keyhole limpet hemocyanin; EGFR: epidermal growth factor receptor; TTF: tumor treating fields; poly-ICLC: polyriboinosinic-polyribocytidylic acid-polylysine carboxymethylcellulose

One of the most successful tumor-specific antigen peptide vaccines against GBM, rindopepimut, uses the EGFRvIII peptide which is expressed in $25 \%-64 \%$ of GBM patients ${ }^{[17]}$. Rindopepimut is commonly coadministered with the keyhole limpet hemocyanin (KLH) and granulocyte-macrophage colony-stimulating factor (GM-CSF) adjuvants. Adjuvants are commonly used to enhance cross-presentation of antigens to improve immunogenicity. A promising phase II trial (ACTIVATe) conducted with rindopepimut and TMZ treatment demonstrated a median OS of 26.0 months [Table 4]. This compared well to controls with a median OS of only 15.0 months (TMZ treatment). Antibody formation against the EGFRvIII peptide was observed in a small subset of patients which correlated with improved median OS, 47.7 months as compared to 22.8 months. However, EGFRvIII negative tumor recurrence was observed in $82 \%$ of patients ${ }^{[73]}$. A larger, phase III clinical trial (ACT IV) was later performed that did not show significant improvement in OS following rindopepimut treatment ${ }^{[7]}$. KLH, an adjuvant given with the peptide vaccine, was administered to the phase III control group but not the phase II control group. This suggests that the improved OS may be attributable to the immunogenicity generated by $\mathrm{KLH}$ alone and not the peptide. Additionally, at larger scales, peptide vaccinations may be limited by heterogeneity of the patient population. Co-administration of rindopepimut with bevacizumab, however, improved OS for patients which suggests combination with antiangiogenic therapies may improve efficacy of immunotherapies ${ }^{[75]}$. 
Clinical trials involving tumor-associated antigens have not shown significant benefit. Survivin, an inhibitor of apoptosis protein family, is highly expressed in all four subtypes of GBM. A phase I clinical trial found that SurVaxM, a survivin peptide vaccine, did not improve OS, though it was shown to induce cellular and humoral immune responses ${ }^{[76]}$ and has moved on to a phase II trial. Similarly, a phase I/II clinical trial using IMA-950, a multi-peptide vaccine, did not significantly improve OS in combination with polyriboinosinicpolyribocytidylic acid-polylysine carboxymethylcellulose and TMZ treatment ${ }^{[77]}$. Similar to SurVaxM, IMA950 induced a measurable increase in $\mathrm{CD}^{+}$and $\mathrm{CD}_{4}{ }^{+} \mathrm{T}$-cell response. Lack of correlation between improved outcomes and a peripheral immune response is a common theme among peptide vaccines, and suggests a disrupted interaction between peripheral immune cells and GBM cells due to the immunosuppressive tumor microenvironment.

Recently, efforts have turned to developing personalized peptide vaccines based on analysis of patients' resected tumors. A phase I clinical trial assessed actively personalized vaccination (APVAC) for improving immunogenicity and survival in GBM patients. APVAC induced a $\mathrm{CD} 4{ }^{+} \mathrm{T}$-cell driven immune response in $90 \%$ of patients, with a median OS of 29 months $^{[78]}$. However, APVAC was less-tolerated than previous peptide vaccines, with adverse events including anaphylactic reactions and cerebral edema which must be addressed for personalized vaccines to advance.

Overall, peptide vaccines have been shown to induce an immune response without a corresponding improvement in OS. The lack of correlation may be attributed to the immunosuppressive tumor microenvironment. Combination therapies with checkpoint inhibitors may provide a more robust response with better survival outcomes. Personalized vaccine therapies offer a unique and potentially effective way to not only prevent initial tumor progression but also recurrent tumor development, and warrant further investigation. An active clinical trial is currently pursuing combining personalized peptide vaccines with checkpoint inhibitors, and will hopefully elucidate the benefit of these combined therapies (NCT03422094).

\section{Induced pluripotent stem cells vaccines}

Stem cell vaccines comprised of embryonic stem cells (ESCs) have been studied for their ability to generate antitumor immunity. This is largely attributed to the common markers expressed by both tumors and

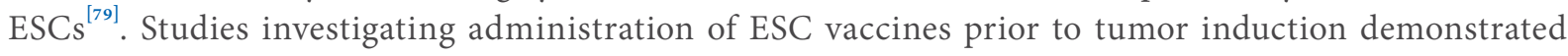
that pre-vaccination could effectively halt tumor growth. However, ethical concerns regarding ESCs limit progress. Focus has now shifted towards induced pluripotent stem cells (iPSCs), which are stem cells derived from somatic cells in combination with Oct3/4, Sox2, c-Myc, and Klf4 transcription factors. The exposure of somatic cells to these transcription factors promotes oncogenic transformation and tumor antigen expression ${ }^{[80]}$. This can lead to improved immunogenicity and more precise targeting of tumor cells. Additionally, iPSCs can be generated from a patient's own tissue and may provide a better representation of a patient's tumor immunogens, although this procedure is not cost-effective.

The use of non-autologous iPSC vaccines can provide a more commercially viable option for iPSC based vaccines. Vaccines generated from iPSCs genetically engineered to express GM-CSF have been shown to suppress lung tumor growth in mice prior to tumor induction as well as in pre-established tumors ${ }^{[8]}$. More recently, an iPSC vaccine comprised of iPSCs with DNA adjuvant CpG demonstrated tumor regression and significantly longer survival in murine models of breast cancer and melanoma. Additionally, treated mice developed antibody titers against iPSCs and tumor cells and were able to protect against tumor rechallenge ${ }^{[82]}$. These data suggest iPSC vaccines may be applicable to other solid tumors, such as GBM.

\section{DC vaccines}

DCs act as the bridge between the innate and adaptive immune system, collecting antigens and presenting them to lymphocytes. DC presentation of antigens to lymphocytes leads to activation of various T- cell populations. These T-cells' respective types and specificity are dependent on the antigens presented by 
the DCs and the context in which the DC presents the antigen. To elicit the appropriate lymphocyte and immune response, DCs must present tumor-specific or tumor-associated antigens, upregulate expression of MHC-I and II in conjunction with adhesion and co-stimulatory molecules, and induce secretion of stimulatory and anti-tumor cytokines including IL-12, IL-15, IL-18, and IFN- $\gamma^{[83]}$.

Certain lymphocytes possess inherent capabilities to fight cancer. However, cancers may lack a sufficient supply of tumor antigens to stimulate this immune response. DC vaccines address the lack of tumor antigen by supplying antigen and stimulation to DCs ex vivo. Patients can then be vaccinated with these tumorspecific DCs. By manipulating DCs, both in terms of the antigens they present and the context by which they do so, activation of lymphocytes can be manipulated in order to yield an anti-tumor response.

Clinical trials using DC vaccines have employed a variety of antigen loading strategies which include pulsing maturing DCs with autologous-tumor lysate ${ }^{[84]}$. In this technique, DCs must be enriched and matured from monocytes obtained from individual patient's peripheral blood mononuclear cells ${ }^{[84-87]}$. The monocytes are then expanded and differentiated into immature DCs through exposure to GM-CSF and IL-4 ${ }^{[88]}$. Immature DCs are loaded with antigens and matured before being administered to patients as a vaccine.

Pulsing maturing DCs with autologous-tumor lysate has made the most progress in GBM therapeutic outcomes. Northwest Biotherapeutics' DCVax ${ }^{-}-\mathrm{L}$ has recently shown positive results in a phase III clinical trial [Table 5]. Patients selected were between 18 and 70 years of age, and had just been newly diagnosed with GBM. Following surgical resection (the source of autologous tumor-lysate) and chemoradiotherapy, patients were given a series of DCVax ${ }^{\oplus}$ - injections in addition to monthly administration of TMZ. Median OS was 23.1 months, with $25.4 \%$ of patients surviving for more than three years post-surgery. This therapy was also well tolerated, with only $2.1 \%$ of patients demonstrating grade 3 or 4 adverse events which may have been related to surgery and chemoradiotherapy ${ }^{[89]}$.

Smaller trials using autologous-tumor lysate pulsed vaccines have demonstrated similar safety and efficacy. In the University of Navarra phase II trial, autologous DC vaccines were administered to 31 patients who had a median OS of 23.4 months ${ }^{[90]}$. The high grade glioma-2006 phase I and II trials administered autologous DC vaccines to 77 patients in total with a median OS of 19.4 months ${ }^{[91]}$, and the phase II DENDR1 trial administered autologous tumor lysate vaccines to 24 patients demonstrated a median OS of 20.1 months ${ }^{[92]}$. Compared to the 14 months OS following GBM diagnosis and standard of care, DC vaccines pulsed with autologous tumor lysate have demonstrated a substantial and consistent increase in OS, with little to no adverse events.

More recent endeavors have sought to tailor protein-specific DC vaccines through lysates composed of select tumor-associated antigens ${ }^{[8]}$ or by transfecting DCs with nucleic acids for tumor-specific or tumorassociated antigen ${ }^{[93]}$, or with cytomegalovirus $\mathrm{RNA}^{[94]}$. A phase I study pulsed DC with lysate containing tumor-associated antigens including human epidermal growth factor receptor 2 (HER2), tyrosinase related protein-2, gp100, melanoma-associated antigen 1 (MAGE-1), IL13R $\alpha 2$, and absent in melanoma 2 (AIM-2), proteins which are enriched in GBM cancer stem cells (GCSC). The multi-epitope-pulsed DC vaccine was used to vaccinate 16 patients with newly diagnosed GBM. Median OS was 38.4 months and improved OS correlated with expression of AIM-2 and MAGE-1 in the tumor. Notably, a decrease was seen in GCSC marker CD133, suggesting that the multi-epitope-pulsed DC vaccine had successfully reduced the population of cancer stem cells ${ }^{[8]}$, potentially accounting for the significant increase in median OS, nearly three times that seen with the standard of care.

Transfection of DC to induce expression of tumor-specific or tumor-associated proteins has also demonstrated success in treating GBM. In a phase I clinical trial GCSC mRNA was isolated from brain 
Table 5. Clinical trials using dendritic vaccines to treat gliomas

\begin{tabular}{|c|c|c|c|c|}
\hline Identifier & Trial name & Treatment & Phase & $\begin{array}{c}\text { Diagnosis (newly } \\
\text { diagnosed or reoccurring) }\end{array}$ \\
\hline NCT00107185 & $\begin{array}{l}\text { Vaccine therapy in treating young patients } \\
\text { who are undergoing surgery for malignant } \\
\text { glioma }\end{array}$ & Autologous DC vaccine & I & Both \\
\hline NCT01171469 & $\begin{array}{l}\text { Vaccination with dendritic cells loaded } \\
\text { with brain tumor stem cells for progressive } \\
\text { malignant brain tumor }\end{array}$ & Autologous DC vaccine & । & Both \\
\hline NCT00639639 & $\begin{array}{l}\text { Vaccine Therapy in treating patients with } \\
\text { newly diagnosed GBM (ATTAC) }\end{array}$ & $\begin{array}{l}\text { DC vaccine with mRNA from } \\
\text { human cytomegalo-virus }\end{array}$ & I & Newly diagnosed \\
\hline EudraCT 2006-002881-20 & HGG-2006 phase I/II trial & Autologous DC vaccine & $\mathrm{I} / \mathrm{II}$ & Newly diagnosed \\
\hline $\begin{array}{l}\text { NCT00846456 (EudraCT } \\
\text { 2007- 006171-37) }\end{array}$ & $\begin{array}{l}\text { Safe study of DC based therapy targeting } \\
\text { tumor stem cells in GBM }\end{array}$ & $\begin{array}{l}\text { DC vaccine with mRNA from } \\
\text { tumor stem cells }\end{array}$ & I/II & Both \\
\hline NCT00323115 & $\begin{array}{l}\text { Phase II feasibility study of DC vaccination } \\
\text { for newly diagnosed GBM }\end{array}$ & Autologous DC vaccine & II & Newly diagnosed \\
\hline EudraCT 2008- 005035-15 & DENDR1 & Autologous DC vaccine & ॥ & Newly diagnosed \\
\hline EudraCT 2008- 005038-62 & DENDR2 & Autologous DC vaccine & $\|$ & Reoccurring \\
\hline NCT03395587 & $\begin{array}{l}\text { Efficiency of vaccination with lysate-loaded } \\
\text { DCs in patients with newly diagnosed GBM } \\
\text { (GlioVax) }\end{array}$ & Autologous DC vaccine & II & Newly diagnosed \\
\hline $\begin{array}{l}\text { NCT01006044 (EudraCT } \\
\text { 2009- 009879-35) }\end{array}$ & $\begin{array}{l}\text { Efficacy \& safety of autologous DC } \\
\text { vaccination in GBM after complete surgical } \\
\text { resection }\end{array}$ & Autologous DC vaccine & II & Newly diagnosed \\
\hline NCT01280552 & A study of ICT-107 immunotherapy in GBM & Multi-epitope pulsed DC vaccine & ॥ & Newly diagnosed \\
\hline NCT02546102 & $\begin{array}{l}\text { Phase } 3 \text { randomized, double-blind, } \\
\text { controlled study of ICT-107 in GBM }\end{array}$ & Multi-epitope pulsed DC vaccine & III & $\begin{array}{l}\text { Newly diagnosed (and } \\
\text { in remission) }\end{array}$ \\
\hline NCT00045968 & $\begin{array}{l}\text { Study of a drug }\left[D C V a x{ }^{\circledR}-L\right] \text { to treat newly } \\
\text { diagnosed GBM brain cancer }\end{array}$ & Autologous DC vaccine & III & Newly diagnosed \\
\hline
\end{tabular}

DC: dendritic cell; GBM: glioblastoma multiforme; HGG: high grade glioma

tumor biopsies and transfected into DC cells used to vaccinate patients. To isolate GCSC, patient tumor cells were selected for their ability to form spheres in vitro as a proxy for identifying cancer stem cells. From the sphere-forming tumor cells, mRNA was isolated and transfected into patient derived DCs, which were used as vaccinations for seven patients. Patients showed no adverse effects and had a median OS of 23 months ${ }^{[95]}$, comparable to that seen in DC vaccines loaded with autologous tumor-lysate.

In addition to cellular proteins, recent studies have shown that a high percentage of GBM express cytomegalovirus proteins, a potential target for DC vaccines. In a phase I clinical trial, 11 patients were vaccinated with DCs transfected with cytomegalovirus pp65 lysosome-associated membrane glycoprotein mRNA, following resection and radiochemotherapy. These patients demonstrated a median OS of 41.1 months, with no adverse effects attributed to the cellular component of treatment ${ }^{[94]}$. If larger studies confirm that a significant number of GBM patient tumors exhibit cytomegalovirus, cytomegalovirus proteins offer a clear target for DC vaccines, and potentially peptide vaccines as well.

One challenge of evaluating DC vaccines has been the lack of consistency across trials to measure immune response. While median OS provides a good measure of general effectiveness, trials vary in measurements when evaluating immunological outcomes, such as cytokine levels or immune cell counts. Trials have shown mixed results as to whether or not DC vaccines increase cytotoxic T-cell and TH1 responses, which is further confounded by trials that did not measure these criteria. Trials that have measured NK cell populations have shown that an increase in NK cell activity and number following vaccinations has been correlated with improved outcomes ${ }^{[86,92]}$. In order to improve the development of DC vaccinations, consistent immunological evaluations (patient T-cell, NK cell, and cytokine production, etc.) offer a clear target so that the mechanisms underlying the success of various aspects of DC vaccinations can be elucidated and better applied going forward. 
While DC vaccines have shown their ability to prolong OS, correlation of immune response with longterm outcomes remains unclear, and prognostic markers for determining patients that will best respond to DC vaccines needs to be further elucidated. DC vaccines targeting specific proteins, the multi-epitope trial and cytomegalovirus trial, show great clinical potential, but must be evaluated on a larger scale before conclusions can be drawn. Whole-tumor lysate vaccines are the most advanced in terms of clinical trial progress and demonstrate clear improvements, with $25 \%$ of patients achieving above a three-year survival rate in the largest phase 3 trial to date. This trial further demonstrated increased efficacy in patients with methylated O6-methylguanine-DNA methyltransferase, offering another potential prognostic marker for identifying patients who might best respond to autologous tumor-lysate DC vaccines ${ }^{[89]}$. For patients whose tumors can be biopsied, DC vaccines offer a significant improvement in survival outcome, which will be enhanced as prognostic markers become clearer.

\section{CONCLUSION}

Glioma-targeted immunotherapy is still in its infancy. Although ACT, NK cells, checkpoint inhibitors and vaccines have proven their efficacy in other cancers, a deeper understanding of the features specific to solid gliomas is necessary for refined therapy adjustment. Furthermore, improved human preclinical models can more accurately illustrate the human CNS microenvironment and immune cell relationships with the BBB. Studies utilizing these models can deepen our understanding of immune function, ultimately revealing ways to enhance combined treatment modalities. Yet as these ambiguities are made clear, the future of these treatments against GBM remains bright. These methods of tumor eradication address limitations posed by conventional surgical, radiation, and chemotherapies.

\section{DECLARATIONS}

\section{Authors' contributions}

Conceptualize the project, write and edit the manuscript: Low WC, Crane AT, Pearce CM, Chrostek MR

Write various sections of the manuscript: Fellows EG, Toman NG, Tran S

\section{Availability of data and materials}

Not applicable.

\section{Financial support and sponsorship}

This work was supported in part by funds from Suzanne M. Schwarz.

\section{Conflicts of interest}

All authors declared that there are no conflicts of interest.

\section{Ethical approval and consent to participate}

Not applicable.

\section{Consent for publication}

Not applicable.

\section{Copyright}

(c) The Author(s) 2018.

\section{REFERENCES}

1. Hanif F, Muzaffar K, Perveen K, Malhi SM, Simjee ShU. Glioblastoma multiforme: a review of its epidemiology and pathogenesis through clinical presentation and treatment. Asian Pac J Cancer Prev 2017;18:3-9.

2. Parker NR, Hudson AL, Khong P, Parkinson JF, Dwight T, et al. Intratumoral heterogeneity identified at the epigenetic, genetic and transcriptional level in glioblastoma. Sci Rep 2016;6:22477. 
3. Carson MJ, Doose JM, Melchior B, Schmid CD, Ploix CC. CNS immune privilege: hiding in plain sight. Immunol Rev 2006;213:48-65.

4. Weller RO, Galea I, Carare RO, Minagar A. Pathophysiology of the lymphatic drainage of the central nervous system: implications for pathogenesis and therapy of multiple sclerosis. Pathophysiology 2010;17:295-306.

5. Jack AS, Lu JQ. Immune cell infiltrates in the central nervous system tumors. Austin Neurosurgery Open Access 2015;2:1024.

6. Wilson EH, Weninger W, Hunter CA. Trafficking of immune cells in the central nervous system. J Clin Invest 2010;120:1368-79.

7. Sagar D, Foss C, El Baz R, Pomper MG, Khan ZK, et al. Mechanisms of dendritic cell trafficking across the blood-brain barrier. J Neuroimmune Pharmacol 2012;7:74-94.

8. Han S, Zhang C, Li Q, Dong J, Liu Y, et al. Tumour-infiltrating CD4(+) and CD8(+) lymphocytes as predictors of clinical outcome in glioma. Br J Cancer 2014;110:2560-8.

9. Skwarczynski M, Toth I. Peptide-based synthetic vaccines. Chem Sci 2016;7:842-54.

10. Golubovskaya V, Wu L. Different subsets of T cells, memory, effector functions, and CAR-T immunotherapy. Cancers (Basel) 2016; doi: $10.3390 /$ cancers8030036.

11. Ostroumov D, Fekete-Drimusz N, Saborowski M, Kühnel F, Woller N. CD4 and CD8 T lymphocyte interplay in controlling tumor growth. Cell Mol Life Sci 2018;75:689-713.

12. Hashimoto M, Kamphorst AO, Im SJ, Kissick HT, Pillai RN, et al. CD8 T cell exhaustion in chronic infection and cancer: opportunities for interventions. Annu Rev Med 2018;69:301-18

13. Gust J, Hay KA, Hanafi LA, Li D, Myerson D, et al. Endothelial activation and blood-brain barrier disruption in neurotoxicity after adoptive immunotherapy with CD19 CAR-T cells. Cancer Discov 2017;7:1404-19.

14. Zhang E, Gu J, Xu H. Prospects for chimeric antigen receptor-modified T cell therapy for solid tumors. Mol Cancer 2018;17:7.

15. Kueberuwa G, Kalaitsidou M, Cheadle E, Hawkins RE, Gilham DE. CD19 CAR T cells expressing IL-12 eradicate lymphoma in fully lymphoreplete mice through induction of host immunity. Mol Ther Oncolytics 2017;8:41-51.

16. Gan HK, Cvrljevic AN, Johns TG. The epidermal growth factor receptor variant III (EGFRvIII): where wild things are altered. FEBS J 2013;280:5350-70.

17. O'Rourke DM, Nasrallah MP, Desai A, Melenhorst JJ, Mansfield K, et al. A single dose of peripherally infused EGFRvIII-directed CAR $\mathrm{T}$ cellsT-cells mediates antigen loss and induces adaptive resistance in patients with recurrent glioblastoma. Sci Transl Med 2017; doi: 10.1126/scitranslmed.aaa0984.

18. Brown CE, Alizadeh D, Starr R, Weng L, Wagner JR, et al. Regression of glioblastoma after chimeric antigen receptor T-Cell therapy. N Engl J Med 2016;375:2561-9.

19. Linette GP, Stadtmauer EA, Maus MV, Rapoport AP, Levine BL, et al. Cardiovascular toxicity and titin cross-reactivity of affinityenhanced T cells in myeloma and melanoma. Blood 2013;122:863-71.

20. Parkhurst MR, Yang JC, Langan RC, Dudley ME, Nathan DA, et al. T cells targeting carcinoembryonic antigen can mediate regression of metastatic colorectal cancer but induce severe transient colitis. Mol Ther 2011;19:620-6.

21. Davila ML, Riviere I, Wang X, Bartido S, Park J, et al. Efficacy and toxicity management of 19-28z CAR T cell therapy in B cell acute lymphoblastic leukemia. Sci Transl Med 2014;6:224ra25.

22. Maude SL, Barrett D, Teachey DT, Grupp SA. Managing cytokine release syndrome associated with novel T cell-engaging therapies. Cancer J 2014;20:119-22.

23. Baum C, Düllmann J, Li Z, Fehse B, Meyer J, et al. Side effects of retroviral gene transfer into hematopoietic stem cells. Blood 2003;101:2099-114.

24. Modlich U, Navarro S, Zychlinski D, Maetzig T, Knoess S, et al. Insertional transformation of hematopoietic cells by self-inactivating lentiviral and gammaretroviral vectors. Mol Ther 2009; 17:1919-28.

25. Morita D, Nishio N, Saito S, Tanaka M, Kawashima N, et al. Enhanced expression of anti-CD19 chimeric antigen receptor in piggyBac transposon-engineered T cells. Mol Ther Methods Clin Dev 2017;8:131-40.

26. Monjezi R, Miskey C, Gogishvili T, Schleef M, Schmeer M, et al. Enhanced CAR T-cell engineering using non-viral Sleeping Beauty transposition from minicircle vectors. Leukemia 2016;31;186-94.

27. Kebriaei P, Singh H, Huls MH, Figliola MJ, Bassett R, et al. Phase I trials using Sleeping Beauty to generate CD19-specific CAR T cells. J Clin Invest 2016;126:3363-76.

28. Martinet L, Smyth MJ. Balancing natural killer cell activation through paired receptors. Nat Rev Immunol 2015;15;243-54.

29. Krasnova Y, Putz EM, Smyth MJ, Souza-Fonseca-Guimaraes F. Bench to bedside: NK cells and control of metastasis. Clin Immunol 2017;177:50-9.

30. Hayakawa Y, Huntington ND, Nutt SL, Smyth MJ. Functional subsets of mouse natural killer cells. Immunol Rev 2006;214:47-55.

31. Kmiecik J, Zimmer J, Chekenya M. Natural killer cells in intracranial neoplasms: presence and therapeutic efficacy against brain tumours. J Neurooncol 2014;116:1-9.

32. McDermott DF, Regan MM, Clark JI, Flaherty LE, Weiss GR, et al. Randomized phase III trial of high-dose interleukin-2 versus subcutaneous interleukin-2 and interferon in patients with metastatic renal cell carcinoma. J Clin Oncol 2005;23:133-41

33. Steele N, Anthony A, Saunders M, Esmarck B, Ehrnrooth E, et al. A phase 1 trial of recombinant human IL-21 in combination with cetuximab in patients with metastatic colorectal cancer. Br J Cancer 2012;106:793-8.

34. Davis ID, Skrumsager BK, Cebon J, Nicholaou T, Barlow JW, et al. An open-label, two-arm, phase I trial of recombinant human interleukin-21 in patients with metastatic melanoma. Clin Cancer Res 2007;13:3630-6.

35. Conlon KC, Lugli E, Welles HC, Rosenberg SA, Fojo AT, et al. Redistribution, hyperproliferation, activation of natural killer cells and CD8 T-cells, and cytokine production during first-in-human clinical trial of recombinant human interleukin-15 in patients with cancer. J Clin Oncol 2015;33:74-82.

36. Ni J, Miller M, Stojanovic A, Garbi N, Cerwenka A. Sustained effector function of IL- 12/15/18-preactivated NK cells against established tumors. J Exp Med 2012;209:2351-65. 
37. Vetter M, Hofer MJ, Roth E, Pircher HP, Pagenstecher A. Intracerebral interleukin 12 induces glioma rejection in the brain predominantly by CD8+ T cells and independently of interferon-gamma. J Neuropathol Exp Neurol 2009;68:525-34.

38. Imamura M, Shook D, Kamiya T, Shimasaki N, Chai SM, et al. Autonomous growth and increased cytotoxicity of natural killer cells expressing membrane-bound interleukin-15. Blood 2014;124:1081-8.

39. Blackburn SD, Shin H, Freeman GJ, Wherry EJ. Selective expansion of a subset of exhausted CD8 T-cells by alphaPD-L1 blockade. Proc Natl Acad Sci U S A 2008;105:15016-21.

40. Freeman GJ, Long AJ, Iwai Y, Bourque K, Chernova T, et al. Engagement of the PD-1 immunoinhibitory receptor by a novel B7 family member leads to negative regulation of lymphocyte activation. J Exp Med 2000;192:1027-34.

41. Keir ME, Liang SC, Guleria I, Latchman YE, Qipo A, et al. Tissue expression of PD-L1 mediates peripheral T-cell tolerance. J Exp Med 2006;203:883-95.

42. Rudd CE, Taylor A, Schneider H. CD28 and CTLA-4 coreceptor expression and signal transduction. Immunol Rev 2009;229:12-26.

43. Juneja VR, McGuire KA, Manguso RT, LaFleur MW, Collins N, et al. PD-L1 on tumor cells is sufficient for immune evasion in immunogenic tumors and inhibits CD8 T cell cytotoxicity. J Exp Med 2017;214:895-904.

44. Beckermann KE, Jolly PC, Kim JY, Bordeaux J, Puzanov I, et al. Clinical and immunologic correlates of response to PD-1 blockade in a patient with metastatic renal medullary carcinoma. J Immunother Cancer 2017;5:1.

45. Beckermann KE, Johnson DB, Sosman JA. PD-1/PD-L1 blockade in renal cell cancer. Expert Rev Clin Immunol 2017;13:77-84.

46. Allen PB, Gordon LI. PD-1 blockade in Hodgkin's lymphoma: learning new tricks from an old teacher. Expert Rev Hematol 2016;9:939-49.

47. Garon EB. Current perspectives in immunotherapy for non-small cell lung cancer. Semin Oncol 2015; doi: 10.1053/ j.seminoncol.2015.09.019.

48. Robert C, Schachter J, Long GV, Arance A, Grob JJ, et al. Pembrolizumab versus ipilimumab in advanced melanoma. N Engl J Med 2015;372:2521-32.

49. Sonpavde G. PD-1 and PD-L1 inhibitors as salvage therapy for urothelial carcinoma. N Engl J Med 2017;376:1073-4.

50. Lipson EJ, Drake CG. Ipilimumab: an anti-CTLA-4 antibody for metastatic melanoma. Clin Cancer Res 2011;17:6958-62.

51. Kwon ED, Foster BA, Hurwitz AA, Madias C, Allison JP, et al. Elimination of residual metastatic prostate cancer after surgery and adjunctive cytotoxic T lymphocyte- associated antigen 4 (CTLA-4) blockade immunotherapy. Proc Natl Acad Sci U S A 1999;96:15074-9.

52. Winograd R, Byrne KT, Evans RA, Odorizzi PM, Meyer AR, et al. Induction of T-cell immunity overcomes complete resistance to PD-1 and CTLA-4 blockade and improves survival in pancreatic carcinoma. Cancer Immunol Res 2015;3:399-411.

53. Reardon DA, Gokhale PC, Klein SR, Ligon KL, Rodig SJ, et al. Glioblastoma eradication following immune checkpoint blockade in an orthotopic, immunocompetent model. Cancer Immunol Res 2016;4:124-35.

54. Wolchok JD, Kluger H, Callahan MK, Postow MA, Rizvi NA, et al. Nivolumab plus ipilimumab in advanced melanoma. N Engl J Med 2013;369:122-33.

55. Moertel CL, Xia J, LaRue R, Waldron NN, Andersen BM, et al. CD200 in CNS tumor-induced immunosuppression: the role for CD200 pathway blockade in targeted immunotherapy. J Immunother Cancer 2014;2:46.

56. Olin M, Ampudia-Mesias E, Xiong Z, Pluhar E, Moertel C. IMMU-11. Targeting the CD200 checkpoint blockade: a new direction for immunotherapy. Neuro Oncol 2017;19:vi114-5.

57. Zeng J, See AP, Phallen J, Jackson CM, Belcaid Z, et al. Anti-PD-1 blockade and stereotactic radiation produce long-term survival in mice with intracranial gliomas. Int J Radiat Oncol Biol Phys 2013;86:343-9.

58. Belcaid Z, Phallen JA, Zeng J, See AP, Mathios D, et al. Focal radiation therapy combined with 4-1BB activation and CTLA-4 blockade yields long-term survival and a protective antigen-specific memory response in a murine glioma model. PLoS One 2014; doi: 10.1371/ journal.pone. 0101764 .

59. Wainwright DA, Chang AL, Dey M, Balyasnikova IV, Kim CK, et al. Durable therapeutic efficacy utilizing combinatorial blockade against IDO, CTLA-4, and PD-L1 in mice with brain tumors. Clin Cancer Res 2014;20:5290-301.

60. Translational Lung Cancer Research. Immunohistochemistry for predictive biomarkers in non-small cell lung cancer. Available from: http://tlcr.amegroups.com/article/view/15648/12897. [Last accessed on 26 Oct 2018]

61. Diggs LP, Hsueh EC. Utility of PD-L1 immunohistochemistry assays for predicting PD-1/PD-L1 inhibitor response. Biomark Res 2017;5:12.

62. Pardoll DM. The blockade of immune checkpoints in cancer immunotherapy. Nat Rev Cancer 2012;12:252-64.

63. Nduom EK, Wei J, Yaghi NK, Huang N, Kong LY, et al. PD-L1 expression and prognostic impact in glioblastoma. Neuro Oncol 2016;18:195-205.

64. Sweis RF, Spranger S, Bao R, Paner GP, Stadler WM, et al. Molecular drivers of the non-T Cell-inflamed tumor microenvironment in urothelial bladder cancer. Cancer Immunol Res 2016;4:563-8.

65. Spranger S, Dai D, Horton B, Gajewski TF. Tumor-residing Batf3 dendritic cells are required for effector T cell trafficking and adoptive T cell therapy. Cancer Cell 2017;31:711-23.

66. Chalmers ZR, Connelly CF, Fabrizio D, Gay L, Ali SM, et al. Analysis of 100,000 human cancer genomes reveals the landscape of tumor mutational burden. Genome Medicine 2017;9:34.

67. Woroniecka K, Chongsathidkiet P, Rhodin K, Kemeny H, Dechant C, et al. T-cell exhaustion signatures vary with tumor type and are severe in glioblastoma. Clin Cancer Res 2018;24:4175-86.

68. Nakashima H, Alayo QA, Penaloza-MacMaster P, Freeman GJ, Kuchroo VK, et al. Modeling tumor immunity of mouse glioblastoma by exhausted CD8+ T-cells. Sci Rep 2018;8:208.

69. Wang M, Yao LC, Cheng M, Cai D, Martinek J, et al. Humanized mice in studying efficacy and mechanisms of PD-1-targeted cancer immunotherapy. FASEB J 2018;32:1537-49.

70. Razavi SM, Lee KE, Jin BE, Aujla PS, Gholamin S, et al. Immune evasion strategies of glioblastoma. Front Surg 2016;3:11. 
71. Rosalia RA, Quakkelaar ED, Redeker A, Khan S, Camps M, et al. Dendritic cells process synthetic long peptides better than whole protein, improving antigen presentation and T-cell activation. Eur J Immunol 2013;43:2554-65.

72. Vigneron N. Human tumor antigens and cancer immunotherapy. Biomed Res Int 2015;2015:948501.

73. Sampson JH, Heimberger AB, Archer GE, Aldape KD, Friedman AH, et al. Immunologic escape after prolonged progression-free survival with epidermal growth factor receptor variant III peptide vaccination in patients with newly diagnosed glioblastoma. J Clin Oncol 2010;28:4722-9.

74. Weller M, Butowski N, Tran DD, Recht LD, Lim M, et al. Rindopepimut with temozolomide for patients with newly diagnosed, EGFRvIII-expressing glioblastoma (ACT IV): a randomised, double-blind, international phase 3 trial. Lancet Oncol 2017;18:1373-85.

75. Reardon DA, Schuster J, Tran DD, Fink KL, Nabors LB, et al. ReACT: overall survival from a randomized phase II study of rindopepimut (CDX-110) plus bevacizumab in relapsed glioblastoma. J Clin Oncol 2015;33:2009.

76. Fenstermaker RA, Ciesielski MJ, Qiu J, Yang N, Frank CL, et al. Clinical study of a survivin long peptide vaccine (SurVaxM) in patients with recurrent malignant glioma. Cancer Immunol Immunother 2016;65:1339-52.

77. Dutoit V, Migliorini D, Patrikidou A, Mayer-Mokler A, Hilf N, et al. IMA950 multipeptide vaccine adjuvanted with poly-ICLC in combination with standard therapy in newly diagnosed HLA-A2 glioblastoma patients. Ann Oncol 2017;28:xi3-5.

78. Wick W, Dietrich PY, Kuttruff S, Hilf N, Frenzel K, et al. GAPVAC-101: First-in-human trial of a highly personalized peptide vaccination approach for patients with newly diagnosed glioblastoma. J Clin Oncol 2018;36:2000.

79. Yaddanapudi K, Mitchell RA, Putty K, Willer S, Sharma RK, et al. Vaccination with embryonic stem cells protects against lung cancer: is a broad-spectrum prophylactic vaccine against cancer possible? PLoS One 2012;7:e42289.

80. Lee AS, Tang C, Rao MS, Weissman IL, Wu JC. Tumorigenicity as a clinical hurdle for pluripotent stem cell therapies. Nat Med 2013;19:998-1004.

81. Inoue $\mathrm{H}$, Watanabe $\mathrm{A}$, Sakamoto $\mathrm{C}$, Narusawa M, Hiramoto T, et al. Vaccination with irradiated induced pluripotent stem cells genetically engineered to produce GM-CSF confers potent t-cells-mediated antitumor immunity. Blood 2013;122:4492.

82. Kooreman NG, Kim Y, de Almeida PE, Termglinchan V, Diecke S, et al. Autologous iPSC-based vaccines elicit anti-tumor responses in vivo. Cell Stem Cell 2018;22:501-13.

83. Soling A, Rainov NG. Dendritic cell therapy of primary brain tumors. Mol Med 2001;7:659-67.

84. Polyzoidis S, Ashkan K. DCVax®-L--Developed by Northwest Biotherapeutics. Hum Vaccin Immunother 2014;10:3139-45.

85. Lasky JL 3rd, Panosyan EH, Plant A, Davidson T, Yong WH, et al. Autologous tumor lysate-pulsed dendritic cell immunotherapy for pediatric patients with newly diagnosed or recurrent high-grade gliomas. Anticancer Res 2013;33:2047-56.

86. Olin MR, Low W, McKenna DH, Haines SJ, Dahlheimer T, et al. Vaccination with dendritic cells loaded with allogeneic brain tumor cells for recurrent malignant brain tumors induces a CD4(+)IL17(+) response. J Immunother Cancer 2014;2:4

87. Phuphanich S, Wheeler CJ, Rudnick JD, Mazer M, Wang H, et al. Phase I trial of a multi-epitope-pulsed dendritic cell vaccine for patients with newly diagnosed glioblastoma. Cancer Immunol Immunother 2013;62:125-35.

88. Felzmann T, Witt V, Wimmer D, Ressmann G, Wagner D, et al. Monocyte enrichment from leukapharesis products for the generation of DCs by plastic adherence, or by positive or negative selection. Cytotherapy 2003;5:391-8.

89. Liau LM, Ashkan K, Tran DD, Campian JL, Trusheim JE, et al. First results on survival from a large phase 3 clinical trial of an autologous dendritic cell vaccine in newly diagnosed glioblastoma. J Transl Med 2018;16:142.

90. Inogés S, Tejada S, de Cerio AL, Gállego Pérez-Larraya J, Espinós J, et al. A phase II trial of autologous dendritic cell vaccination and radiochemotherapy following fluorescence-guided surgery in newly diagnosed glioblastoma patients. J Transl Med 2017;15:104.

91. Ardon H, Van Gool SW, Verschuere T, Maes W, Fieuws S, et al. Integration of autologous dendritic cell-based immunotherapy in the standard of care treatment for patients with newly diagnosed glioblastoma: results of the HGG-2006 phase I/II trial. Cancer Immunol Immunother 2012;61:2033-44.

92. Pellegatta S, Eoli M, Cuccarini V, Anghileri E, Pollo B, et al. Survival gain in glioblastoma patients treated with dendritic cell immunotherapy is associated with increased NK but not CD8+ T cell activation in the presence of adjuvant temozolomide. OncoImmunology 2018;7:e1412901.

93. Fadul CE, Fisher JL, Hampton TH, Lallana EC, Li Z, et al. Immune response in patients with newly diagnosed glioblastoma multiforme treated with intranodal autologous tumor lysate-dendritic cell vaccination after radiation chemotherapy. J Immunother 2011;34:382-9.

94. Batich KA, Reap EA, Archer GE, Sanchez-Perez L, Nair SK, et al. Long-term survival in glioblastoma with Cytomegalovirus pp65targeted vaccination. Clin Cancer Res 2017;23:1898-1909.

95. Vik-Mo EO, Nyakas M, Mikkelsen BV, Moe MC, Due-Tønnesen P, et al. Therapeutic vaccination against autologous cancer stem cells with mRNA-transfected dendritic cells in patients with glioblastoma. Cancer Immunol Immunother 2013;62:1499-509. 